\section{To: (Receiving Organization) Distribution}

5. Proj./Prog./Dept./Div.:

Spent Nuclear Fuel Project

8. Originator Remarks:

For approval and release.

11. Receiver Remarks
3. From: (originating Organization) Numatec Hanford Corporation Sludge Treatment Project

6. Design Authority/ Design Agent/Cog. Engr.:

A. G. Westra
4. Related EDT No.:

NA

7. Purchase Order No.:

NA

9. Equip./Component No.:

NA

10. System/Bldg./Facility:

NA

12. Major Assm. Dwg. No.:

NA

13. Permit/Permit Application No.: NA

14. Required Response Date:

NA

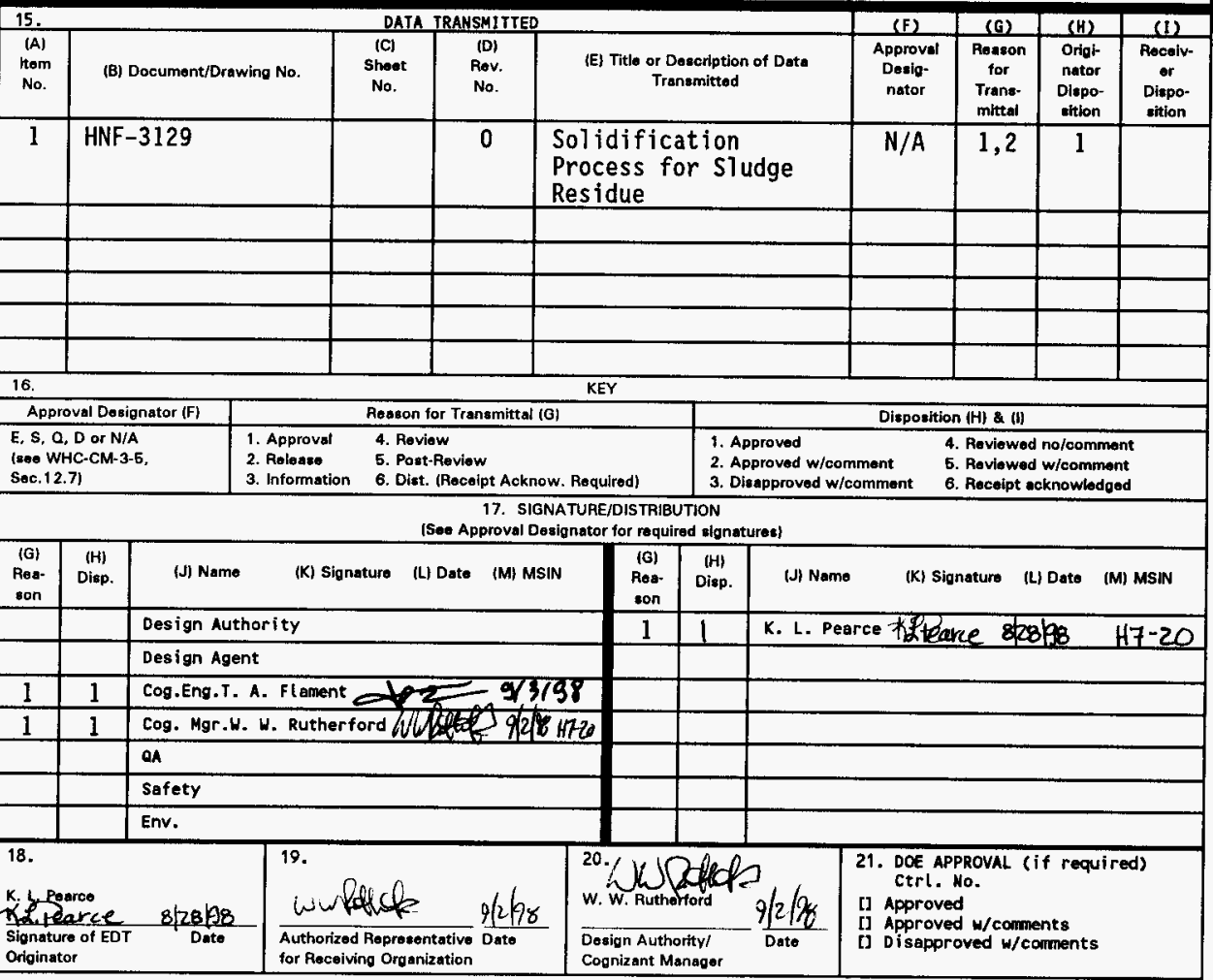


HNF-3129, Rev. 0

\title{
SOLIDIFICATION PROCESS FOR SLUDGE RESIDUE
}

\author{
K. L. Pearce
}

Numatec Hanford Corporation, Richland, WA 99352

U.S. Department of Energy Contract DE-AC06-96RL13200

$\begin{array}{lll}\text { EDT/ECN: } & 624547 & \text { UC: } 2000 \\ \text { Org Code: } & 8 C 700 & \text { Charge Code: LD451 } \\ \text { B\&R Code: } & \text { EW7040000 } & \text { Total Pages: 2728 } 8 \text { क }-98-98\end{array}$

Key Words: Solidification, Sludge, K Basin, Treatment, SNF Project

Abstract: This report investigates the solidification process used at 100-N Basin to solidify the $\mathrm{N}$ Basin sediment and assesses the $\mathrm{N}$ Basin process for application to the $K$ Basin sludge residue material. This report also includes a discussion of a solidification process for stabilizing filters. The solidified matrix must be compatible with the Environmental Remediation Disposal Facility acceptance criteria.

TRADEMARK DISCLAIMER. Reference herein to any specific commercial product, process, or service by trade name, trademark, manufacturer, or otherwise, does not necessarily constitute or imply its endorsement, recommendation, or favoring by the United States Government or any agency thereof or its contractors or subcontractors.

Printed in the United States of America. To obtain copies of this document, contact: Document Control Services, P.O. Box 950, Mailstop H6-08, Richland WA 99352, Phone (509) 372-2420; Fax (509) $376-4989$.

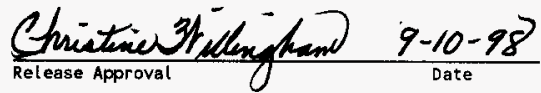



Release Stamp 
HNF-3129, Rev. 0

\title{
SOLIDIFICATION PROCESS FOR SLUDGE RESIDUE
}

K. L. Pearce (NHC)

\author{
Numatec Hanford Corporation \\ Richland, Washington
}

\author{
Issued by \\ NUMATEC HANFORD CORPORATION \\ for the \\ U.S. DEPARTMENT OF ENERGY \\ RICHLAND OPERATIONS OFFICE \\ RICHLAND, WASHINGTON
}


HNF-3129, Rev. 0

TABLE OF CONTENTS

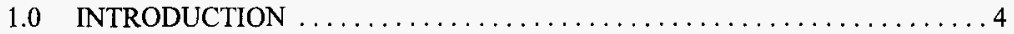



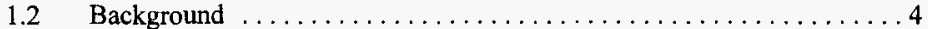

$2.0 \quad$ N BASIN SEDIMENT DISPOSAL $\ldots \ldots \ldots \ldots \ldots \ldots \ldots \ldots \ldots \ldots \ldots$

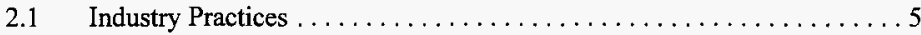

$2.2 \quad \mathrm{~N}$ Basin Sediment Characteristics $\ldots \ldots \ldots \ldots \ldots \ldots \ldots \ldots \ldots \ldots, \ldots \ldots \ldots$

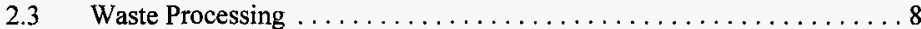

2.3.1 Homogenization $\ldots \ldots \ldots \ldots \ldots \ldots \ldots \ldots \ldots \ldots$

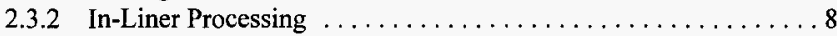

2.3.3 Final N Basin Sediment Waste Form . . . . . . . . . . . . . . 9

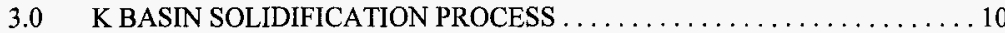

3.1 Composition of Residue and Comparison to N Basin Sediment ...... 10

3.2 Application of N Basin Solidification Process $\ldots \ldots \ldots \ldots \ldots \ldots 11$

3.2.1 Solidification of Special-Case Materials . . . . . . . . . . . 11

$3.2 .2 \quad \mathrm{~K}$ Basin Residue ............................ 12

3.2.3 Cartridge Filters . . . . . . . . . . . . . . . . . . . 13



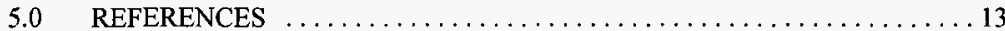

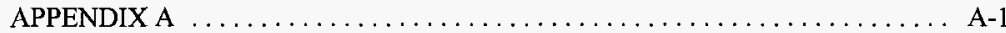

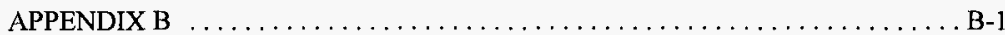

\section{LIST OF TABLES}

2-1 Chemical and Physical Characteristics of N Basin As-Settled Sediment . . . . . . . . . 7

2-2 Radionuclide Characteristics of N Basin As-Settled Sediment ................ 7

2-3 Liner Material Masses and Weight Percent ....................... 10

3-1 Comparison of K Basin Residue to N Basin Sediment on Dry Solids Basis . . . . . . . . 10

3-2 Solidified Waste Concentrations vs ERDF Limits .................... 12 


\section{HNF-3129, Rev. 0}

\section{LIST OF TERMS}

$\begin{array}{ll}\text { BHI } & \text { Bechtel Hanford Incorporated } \\ \text { CNS } & \text { Chem Nuclear Systems } \\ \text { CWC } & \text { Central Waste Complex } \\ \text { ERDF } & \text { Environmental Restoration Disposal Facility } \\ \text { KE } & \text { K East } \\ \text { KW } & \text { K West } \\ \text { NCP } & \text { North Cask Pit } \\ \text { OIER } & \text { Organic Ion Exchange Resin } \\ \text { PCB } & \text { Polychlorinated Biphenyl } \\ \text { RCRA } & \text { Resource Conservation and Recovery Act } \\ \text { SNF } & \text { Spent Nuclear Fuel } \\ \text { TSCA } & \text { Toxic Substances Control Act } \\ \text { TRU } & \text { Transuranic } \\ \text { USNRC } & \text { U.S. Nuclear Regulatory Commission } \\ \text { WIPP } & \text { Waste Isolation Pilot Plant }\end{array}$




\section{HNF-3129, Rev. 0}

\subsection{INTRODUCTION}

\subsection{Purpose}

The purpose of this report is to investigate the solidification process used at 100-N Basin to solidify the $\mathrm{N}$ Basin sediment and to assess its application to the $\mathrm{K}$ Basin sludge residue material. This report also includes a discussion of a solidification process for stabilizing filters. The solidified material must be compatible with the Environmental Remediation Disposal Facility (ERDF) acceptance criteria.

\subsection{Background}

Both the $\mathrm{K}$ East $(\mathrm{KE})$ and $\mathrm{K}$ West $(\mathrm{KW})$ Basins contain contaminated sludge. Sludge on the floor and in the pits of the KE Basin is a mix of fuel corrosion products (including metallic uranium, and fission and activation products), small fuel fragments, zirconium cladding, iron and aluminum oxide, concrete grit, sand, ion exchange resin and biological debris. The large quantity of fuel corrosion products in the KE Basin floor and pit sludge is a result of the open tops, and in some cases open-screened bottoms, of the fuel storage canisters. Because the Spent Nuclear Fuel (SNF) stored in the KW Basin was placed in closed containers before storage, corrosion products were retained within the canisters and the sludge buildup in the KW Basin is a much smaller volume than that in KE Basin. The small quantity of sludge on the floor of the KW Basin appears to consist primarily of dust and sediment; the floor sludge is not expected to contain significant amounts of fuel corrosion products because the KW Basin canisters have closed tops and bottoms. Only one of the pits (North Loadout Pit) in the KW Basin contains a significant amount of sludge and is likely to consist of a mix of sand and fuel corrosion products. Sludge in the KE and KW Basin fuel storage canisters consists primarily of fuel corrosion products.

The baseline path for disposal of the K Basin sludge is to chemically treat the sludge by separating the organic resin material, dissolving the fuel constituents in nitric acid, separating the insoluble material, adding neutron absorbers for criticality safety, and then reacting the solution with caustic to co-precipitate the uranium and plutonium.

There will be five distinct feed streams going to the sludge treatment process, two from KE Basin and three from $\mathrm{KW}$ Basin. The characteristics of these five feed streams are documented in Pearce (1998). The sludge, from one feed stream at a time, will be transported to the treatment system lag storage tank where it will be held until it can be moved on through the process. From the lag storage tank the sludge will be transferred through a screen to the dissolver feed tank. The screen will separate out the organic resin beads and direct them to a resin holding tank. The undissolved solids in the dissolver product will be separated out using a sedimentation centrifuge followed by a polishing filter (cartridge filter with polyethylene filter elements). The solids that are removed by the centrifuge will be transferred to a leaching tank where Transuranic (TRU) and 


\section{HNF-3129, Rev. 0}

fission products will be leached from the solids. The resin beads will also be transferred to the leach tank where they will be treated to remove Cs-137 and transuranics. Following leaching, the leach solution and washed resin beads/solids will be sent to the centrifuge for separation. The overflow from the centrifuge will be transferred through cartridge filters for further solids separation. The separated resin beads and undissolved solids will then be transferred to a holding tank until processed for final disposal.

The pressure drop across the filter will be monitored and the filter elements will be changed out when the pressure drop approaches the design limit or when the flow rate through the filter decreases to the point that it is slowing down sludge processing. The filters will be stored until processed for final disposal at the completion of the sludge treatment process. A complete description of the sludge treatment process, including the solids/liquid separations for the resin beads and undissolved solids, is provided in Westra (1998).

\subsection{N BASIN SEDIMENT DISPOSAL}

105-N Basin sediment consisted of corrosion product (e.g., reactor fuel element, structural steel, and aluminum oxide corrosion), windblown sand and dirt, biological debris, and organic flocculation material. During stabilization of the 105-N Basin, the basin sediments were collected in the North Cask Pit (NCP) of the basin complex. The consolidated sediment was subject to Toxic Substances Control Act (TSCA) regulation, but was not a Resource Conservation and Recovery Act (RCRA) waste. The mass of the settled sediments (solids plus interstitial water) in the NCP was calculated to be $13,636 \mathrm{~kg}$. The final sediment volume was $401 \mathrm{ft}^{3}\left(11.36 \mathrm{~m}^{3}\right)$ based on a wet, settled condition (corresponding density: $1.20 \mathrm{~g} / \mathrm{cc}$ ). The $\mathrm{N}$ Basin Project solidified the sediment and disposed of the waste at the ERDF in accordance with the ERDF waste acceptance criteria and applicable regulations. The project completed solidification of the N Basin sediment in July 1998.

This section provides an overview of the solidification process used at N Basin (Logan 1998).

\subsection{Industry Practices}

In developing plans for the disposal of the $\mathrm{N}$ Basin sediment, Bechtel Hanford Incorporated (BHI) evaluated industry practices for similar waste processing activities to ensure conformance:

- The U.S. Nuclear Regulatory Commission (USNRC) Branch Technical Position titled Issuance of Final Branch Technical Position on Concentration Averaging and Encapsulation. Revision in Part to Waste Classification Technical Position (January 17, 1995) states that "Classification of evaporator concentrates, filter backwashes, liquids, or ion-exchange resins solidified in a manner to achieve homogeneity or meet the stability criteria of 10 CFR 61.56 should be based on solidified nuclide activity divided by the 


\section{HNF-3129, Rev. 0}

volume or weight of the solidified mass." This text establishes the commercial nuclear precedent for averaging the activity over the volume or mass of the final waste matrix.

Solidification is an established method of removing freestanding water and satisfying waste form and structural stability criteria. The Chem Nuclear process is approved by the USNRC, and used in commercial nuclear power plants for the disposal of various waste resins.

- Commercial nuclear processing relies on tank recirculation times and process flow rates to ensure adequate homogenization before commencing waste processing operations. A similar approach was used for the N Basin NCP contents. The USNRC position on activity averaging referenced above states that:

"A homogeneous waste type is one in which the radionuclide concentrations are likely to approach uniformity in the context of the intruder scenarios used to establish the values included in Tables 1 and 2 of 10 CFR 61.55 (i.e., intruder interactions with the waste are assumed to take place 100 years or more after disposal site closure). Such waste types would include, for example, spent ion-exchange resins, filter media, solidified liquid, evaporator bottom concentrates, or contaminated soil."

Therefore, with proper consideration during the design process, homogeneity may be assumed after the NCP contents are mixed. (Analytical validation of homogeneity is not required.)

- The ratio of the total volume of the $\mathrm{N}$ Basin waste matrix after processing to the volume of material before processing was about $6: 1$. This ratio is consistent with industry experience in solidifying liquid radioactive waste. 


\section{HNF-3129, Rev, 0}

\subsection{N Basin Sediment Characteristics}

The physical, chemical and radiological characteristics of the consolidated $\mathrm{N}$ Basin sediment, on an as-settled basis, are presented in Tables 2-1 and 2-2 (partial list, only, provided [Logan 1998]).

Table 2-1. Chemical and Physical Characteristics of N Basin As-Settled Sediment.

\begin{tabular}{|l|c|l|l|l|l||}
\hline \multicolumn{1}{|c|}{ Analyte } & Concentration & Units & Physical Property & \multicolumn{1}{c|}{ Value } & Units \\
\hline Aluminum & $1.02 \mathrm{E}+04$ & $\mu \mathrm{g} / \mathrm{g}$ & Settled Density & $1.20 \mathrm{E}+00$ & $\mathrm{~g} / \mathrm{mL}$ \\
\hline Calcium & $5.60 \mathrm{E}+03$ & $\mu \mathrm{g} / \mathrm{g}$ & Slurry Density & $1.09 \mathrm{E}+00$ & $\mathrm{~g} / \mathrm{mL}$ \\
\hline Iron & $1.10 \mathrm{E}+05$ & $\mu \mathrm{g} / \mathrm{g}$ & Percent $\mathrm{H}_{2} \mathrm{O}$ & $5.61 \mathrm{E}+01$ & $\%$ \\
\hline Silicon & $1.44 \mathrm{E}+03$ & $\mu \mathrm{g} / \mathrm{g}$ & Sediment Volume & 11.36 & $\mathrm{~m}^{3}$ \\
\hline Uranium & $2.24 \mathrm{E}+03$ & $\mu \mathrm{g} / \mathrm{g}$ & Slurry Volume & 22.91 & $\mathrm{~m}^{3}$ \\
\hline Zirconium & $1.52 \mathrm{E}+01$ & $\mu \mathrm{g} / \mathrm{g}$ & Particle Size & up to 6350 & $\mu \mathrm{m}$ \\
\hline PCBs & & & & & \\
\hline Aroclor 1254 & $22.5 \mathrm{E}+00$ & $\mu \mathrm{g} / \mathrm{g}$ & & & \\
\hline \hline
\end{tabular}

Table 2-2. Radionuclide Characteristics of N Basin As-Settled Sediment.

\begin{tabular}{|c|c|c|c|c|c|}
\hline Radionuclide & Concentration & Unit & Radionuclide & Concentration & Unit \\
\hline Am-241 & $5.23 \mathrm{E}-01$ & $\mu \mathrm{Ci} / \mathrm{g}$ & Pu-241 & $2.22 \mathrm{E}+01$ & $\mu \mathrm{Ci} / \mathrm{g}$ \\
\hline$A m-242 m$ & $1.02 \mathrm{E}-03$ & $\mu \mathrm{Ci} / \mathrm{g}$ & Pu-242 & $8.96 \mathrm{E}-05$ & $\mu \mathrm{Ci} / \mathrm{g}$ \\
\hline Am-243 & $3.84 \mathrm{E}-03$ & $\mu \mathrm{Ci} / \mathrm{g}$ & U-234 & $1.52 \mathrm{E}-03$ & $\mu \mathrm{Ci} / \mathrm{g}$ \\
\hline Cs-137 & $3.08 \mathrm{E}-00$ & $\mu \mathrm{Ci} / \mathrm{g}$ & U-235 & 3.55E-05 & $\mu \mathrm{Ci} / \mathrm{g}$ \\
\hline Co-60 & $1.24 \mathrm{E}-00$ & $\mu \mathrm{Ci} / \mathrm{g}$ & U-236 & 1.49E-04 & $\mu \mathrm{Ci} / \mathrm{g}$ \\
\hline $\mathrm{Cm}-243$ & $5.41 \mathrm{E}-04$ & $\mu \mathrm{Ci} / \mathrm{g}$ & U-238 & $6.82 \mathrm{E}-04$ & $\mu \mathrm{Ci} / \mathrm{g}$ \\
\hline Np-237 & $1.70 \mathrm{E}-03$ & $\mu \mathrm{Ci} / \mathrm{g}$ & $\mathrm{Sr}-90$ & $2.53 \mathrm{E}-00$ & $\mu \mathrm{Ci} / \mathrm{g}$ \\
\hline Pu-238 & $9.17 \mathrm{E}-02$ & $\mu \mathrm{Ci} / \mathrm{g}$ & & & \\
\hline Pu-239 & $3.39 \mathrm{E}-01$ & $\mu \mathrm{Ci} / \mathrm{g}$ & Gross Alpha & $1.01 \mathrm{E}-00$ & $\mu \mathrm{Ci} / \mathrm{g}$ \\
\hline $\mathrm{Pu}-240$ & $2.01 \mathrm{E}-01$ & $\mu \mathrm{Ci} / \mathrm{g}$ & Gross Beta & $1.11 \mathrm{E}+01$ & $\mu \mathrm{Ci} / \mathrm{g}$ \\
\hline
\end{tabular}




\section{HNF-3129, Rev. 0}

\subsection{Waste Processing}

\subsubsection{Homogenization}

The N Basin sediment was homogenized in the NCP prior to removal of the sediment for solidification. An array of four pumps, with a combined flow rate of about $800 \mathrm{gpm}$, were each placed about two feet out from a corner of the Pit. The final contents of the NCP were mixed and allowed to settle. Following mixing and settling it was expected that the sediment in the NCP was homogeneously distributed in the horizontal plane and stratified in the vertical plane. Treating the waste in order to create separate, equivalent containers of solidified waste assumes that the waste is homogeneous when it is withdrawn from the NCP. It was estimated that the amount of water required for homogenization and removal operations $\left(408 \mathrm{ft}^{3}\left[11.55 \mathrm{~m}^{3}\right]\right)$ was approximately equal to the volume of settled sediment $\left(401 \mathrm{ft}^{3}\left[11.36 \mathrm{~m}^{3}\right]\right)$. The water also provides shielding for the sediment in the Pit.

\subsubsection{In-Liner Processing}

The N Basin slurried material was transferred to commercial L14-170 liners. The internal volume of each liner is $170 \mathrm{ft}^{3}\left(4.81 \mathrm{~m}^{3}\right)$ supplied by Chem Nuclear Systems (CNS) and processed using the CNS 4313-01354-01NP-A Mobile Cement Solidification System. This system has been approved by the USNRC for use in commercial nuclear power plants.

Three liners at a time (each placed inside a concrete shield plug) were located in the basin for processing. Each liner is equipped with an internal, full-span, mixing paddle connected to a fill head assembly by a hydraulic drive assembly/clutch. After the proper volume of sediment slurry was transferred to each of the three liners (measured by a line inside the liner), the solidification ingredients were added through a fill head to one liner at a time. The mixing paddle drive was engaged during introduction of the solidification agents. The paddle continued to turn until the cement was solidified to the point that the hydraulic drive clutch "slipped." The fill head was then removed from the liner (the mixing paddle remains) and moved to the next liner to be solidified. After all three liners were filled, they were moved outside of the basin to cure. Thermocouples were placed inside each liner. Exotherms indicated the liner was ready for transportation to the ERDF. Approximately three liners per week were solidified and sent to ERDF. It required 28 liners to solidify all of the $\mathrm{N}$ Basin sediment.

The only testing that was required for the $\mathrm{N}$ Basin sediment was to perform a bench-scale grout test using actual basin sediment. The test was conducted to verify the grout matrix would solidify and there would be no free standing water.

The grout operation went fairly smooth. The only failures were transfer seals in a couple of the pumps used to homogenize the sediment. The process produced only incidental waste (rags, protective clothing, etc.); the fill head was decontaminated and returned to CNS. Completion of 


\section{HNF-3129, Rev. 0}

the project took approximately 9 months from the time of acquiring Phase 2 characterization samples to shipment of the last liner to ERDF.

\subsubsection{Final N Basin Sediment Waste Form}

The following calculations provide an approximation of the mix of sediment, solidification agent and additional water in each liner:

Total amount of "as-found" waste $=401 \mathrm{ft}^{3}$ (wet sediment) $+408 \mathrm{ft}^{3}$ (NCP water for pumping/homogenization) $=809 \mathrm{ft}^{3}$

Slurry/liner $=809 \mathrm{ft}^{3} / 28$ liners $=29 \mathrm{ft}^{3}$

Volume of grout $=170 \mathrm{ft}^{3}$ (volume of liner) $-29 \mathrm{ft}^{3}=141 \mathrm{ft}^{3}$

Volume of Additional $\mathrm{H}_{2} \mathrm{O}=141 \mathrm{ft}^{3} /\left(27 \mathrm{ft}^{3} / \mathrm{yd}\right)=5.22$ yd grout

5.22 yd grout $x 44$ gal $\mathrm{H}_{2} \mathrm{O} / \mathrm{yd}$ grout $=230 \mathrm{gal}_{2} \mathrm{O}$

$230 \mathrm{gal} \mathrm{H}_{2} \mathrm{O} / 7.48 \mathrm{gal} / \mathrm{f}^{3}=30.7 \mathrm{ft}^{3}=0.870 \mathrm{~m}^{3}$

NOTE: Common grout mixtures require at least 40 gallons of water per yard of grout. The amount of water required to grout the $\mathrm{N}$ Basin sediment was approximately 44 gallons of water per yard of grout.

Given that the mass of the $\mathrm{N}$ Basin as-settled sediment is $13,636 \mathrm{~kg}$ and contains $56.1 \mathrm{wt} \%$ water and assuming the final solidified liner density is $1762 \mathrm{~kg} / \mathrm{m}^{3}$, the mass of materials in each liner is calculated as:



Table 2.3 provides a summary of the above calculations and the $\mathrm{wt} \%$ of the liner materials. 
HNF-3129, Rev. 0

Table 2.3. Liner Material Masses and Weight Percent.

\begin{tabular}{|c|c|c||}
\hline Material & Mass (kg) & Wt \% \\
\hline \hline Dry Sediment & 214 & 2.52 \\
\hline $\begin{array}{c}\text { Total Water (Interstitial + } \\
\text { NCP+ Additional) }\end{array}$ & 1556 & 18.34 \\
\hline Solidification Agent & 6712 & 79.14 \\
\hline
\end{tabular}

\subsection{K BASIN SOLIDIFICATION PROCESS}

\subsection{Composition of Residue and Comparison to N Basin Sediment}

The physical, chemical, and radiological characteristics of the resin material and insoluble solids generated during chemical treatment are presented in Appendix A. The characteristics of the contaminated water used in the solidification process is also given in Appendix A. The characteristics of the filters are presented in Appendix A. The data were excerpted from Westra (1998). Table 3-1 provides a comparison of the major constituents in K Basin residue (from Appendix A), to the $\mathrm{N}$ Basin sediment constituents. The $\mathrm{K}$ Basin residue consists of the insoluble solids and the resins.

Table 3-1. Comparison of K Basin Residue to N Basin Sediment on Dry Solids Basis.

\begin{tabular}{|l|l|l||l|l|l||}
\hline Analyte & $\begin{array}{c}\text { K Basin } \\
\text { Concentration } \\
(\mu \mathrm{g} / \mathrm{g})\end{array}$ & $\begin{array}{c}\text { N Basin } \\
\text { Concentration } \\
(\mu \mathrm{g} / \mathrm{g})\end{array}$ & Isotope & $\begin{array}{c}\text { K Basin } \\
\text { Concentration } \\
(\mu \mathrm{Ci} / \mathrm{g})\end{array}$ & $\begin{array}{c}\text { N Basin } \\
\text { Concentration } \\
(\mu \mathrm{Ci} / \mathrm{g})\end{array}$ \\
\hline Aluminum & $4.99 \mathrm{E}+03$ & $2.32 \mathrm{E}+04$ & Am-241 & $2.63 \mathrm{E}-02$ & $1.19 \mathrm{E}+00$ \\
\hline Iron & $5.43 \mathrm{E}+03$ & $2.51 \mathrm{E}+05$ & Cs-137 & $1.25 \mathrm{E}+01$ & $7.02 \mathrm{E}+00$ \\
\hline Carbon & $3.42 \mathrm{E}+03$ & not listed & Pu-238 & $2.12 \mathrm{E}-02$ & $2.09 \mathrm{E}-01$ \\
\hline Calcium & $2.11 \mathrm{E}+03$ & $1.28 \mathrm{E}+04$ & Pu-239 & $4.78 \mathrm{E}-02$ & $7.72 \mathrm{E}-01$ \\
\hline Silicon & $3.54 \mathrm{E}+05$ & $3.28 \mathrm{E}+03$ & Pu-240 & $4.78 \mathrm{E}-02$ & $4.58 \mathrm{E}-01$ \\
\hline Uranium & $2.14 \mathrm{E}+02$ & $5.10 \mathrm{E}+03$ & Sr-90 & $6.22 \mathrm{E}-01$ & $5.76 \mathrm{E}+00$ \\
\hline Zirconium & $1.98 \mathrm{E}+04$ & $3.46 \mathrm{E}+01$ & & & \\
\hline
\end{tabular}




\section{HNF-3129, Rev, 0}

The isotope concentrations related to TRU determination show the N Basin sediment concentrations are approximately ten times higher than those predicted for the $\mathrm{K}$ Basin residue. Most of the analyte concentrations for $\mathrm{K}$ Basin residue are also much less than the $\mathrm{N}$ Basin sediments' (10 times for aluminum and uranium, and 100 times for iron). The exception is zirconium (comes from zircalloy cladding pieces generated during the fuel cleaning operation) which shows the $\mathrm{K}$ Basin residue concentrations are significantly higher than the sediments'. Additionally, the $\mathrm{K}$ Basin residue will contain organic ion exchange resin (OIER) material (approximately $1.20 \mathrm{E}+05 \mu \mathrm{g} / \mathrm{g}$ ).

\subsection{Application of $\mathbf{N}$ Basin Solidification Process}

\subsubsection{Solidification of Special-Case Materials}

Two materials in the K Basin sediment which were not seen in large quantities in the N Basin sediment are the organic resin beads and the zircalloy cladding (identified in the ERDF acceptance criteria as special-case waste types). ERDF requires that resins be stabilized before they are transported to prevent reaction with their surroundings and generation of excessive heat. If the material is capable of generating gas, the containers shall be vented and/or a catalyst pack may be required. Additionally, the resins may be subject to restrictions associated with organic carbonaceous compounds. If the OIER is designated a dangerous/hazardous waste, and contains greater than $10 \%$ organic/carbonaceous compounds it is restricted from disposal at the ERDF (see Appendix B), and must be incinerated. This criteria is interpreted as applying to resin beads which are dewatered then placed in a drum (i.e., no drying is required, removal of free liquids is sufficient) for disposal at the ERDF. In the sludge treatment process, the resin beads will be combined with the residue and be part of the solidified waste matrix. In this matrix, the organic carbonaceous compounds will be less than $10 \%$. The Chem Nuclear solidification process has been used in commercial nuclear power plants for the disposal of waste resins. Other commercial companies (such as SGN) also have approved solidification systems which have been used to solidify resins (Monsch 1995).

ERDF restricts disposal of pyrophoric materials (zirconium cladding may be pyrophic under certain conditions) unless treated, prepared, and packaged to be nonflammable prior to being disposed. In a solidified waste matrix, the zirconium would be nonflammable. Because hulls and end-pieces separated from irradiated fuel have been embedded in a cement grout in the head-end process at the La Hague UP3 plant in La Hague, France, (Bernard 1994), it is concluded that the solidification process used at $\mathrm{N}$ Basin would be feasible for solidifying the zircalloy cladding pieces. 
HNF-3129, Rev. 0

\subsubsection{K Basin Residue}

Application of the $\mathrm{N}$ Basin solidification process to the $\mathrm{K}$ Basin sludge residue requires capturing the residue from each process stream and storing the material in a holding tank until treatment of all of the K Basins sludge has been completed. Since a large portion of water will be transferred with the residue to the holding tank, a decant operation will be performed to remove excess water. The remaining volume of water will be sufficient for homogenizing the residue and for pumping the residue into the liners. Assuming each liner contains $15 \mathrm{wt} \%$ solids (N Basin liners have about three wt\% solids), then 7 of the commercial L14-170 liners (supplied by CNS) would be required to solidify all of the $\mathrm{K}$ Basin residue. If three liners are solidified per week, it would take about three weeks to solidify all of the $\mathrm{K}$ Basin residue.

The characteristics of the solidified waste in the liners is provided in Appendix A. Applying the same methods used by the $\mathrm{N}$ Basin project, for calculating radionuclide and TRU concentrations in the solidified waste matrix, resulted in concentrations which are below the ERDF acceptance criteria (summary of criteria provided in Appendix B). Table 3-2 presents the results for the radionuclide and TRU concentrations in the solidified liners.

Table 3-2. Solidified Waste Concentrations vs ERDF Limits.

\begin{tabular}{|l|c|c||}
\hline Constituent & $\begin{array}{c}\text { Solidified Waste } \\
\text { Concentrations } \\
\left(\mathbf{C i} / \mathbf{m}^{3}\right)\end{array}$ & $\begin{array}{c}\text { ERDF Limits } \\
\left(\mathbf{C i} / \mathbf{m}^{3}\right)\end{array}$ \\
\hline \hline Americium-241 & $2.9 \mathrm{E}-02$ & $5.0 \mathrm{E}-02$ \\
\hline Cesium-137 & $3.8 \mathrm{E}+00$ & $3.2 \mathrm{E}+01$ \\
\hline Plutonium-238 & $7.0 \mathrm{E}-03$ & $1.5 \mathrm{E}+00$ \\
\hline Plutonium-239 & $1.4 \mathrm{E}-02$ & $2.9 \mathrm{E}-02$ \\
\hline Plutonium-240 & $1.4 \mathrm{E}-02$ & $2.9 \mathrm{E}-02$ \\
\hline Strontium-90 & $1.9 \mathrm{E}-01$ & $7.0 \mathrm{E}+03$ \\
\hline TRU: & $31 \mathrm{nCi} / \mathrm{g}$ & $<100 \mathrm{nCi} / \mathrm{g}$ \\
\hline
\end{tabular}




\section{HNF-3129, Rev. 0}

\subsubsection{Cartridge Filters}

It is predicted that the pressure drop across a cartridge filter used in the solid/liquid separation step will reach the design limit when the wet solids load on a cartridge is about $30 \mathrm{~kg}$. This solids loading will result in the use of about 49 cartridge filters during processing of the sludge. Three options exist for the cartridge filters used in the solid/liquid separation step based on the TRU and PCB concentrations:

- The used cartridge filters which are non TRU ( 46$)$ will be grouted, one each, in 55 gallon drums for disposal at the ERDF.

- The used cartridge filters $(\sim 1)$ which exceed the TRU limit for the ERDF but are below the Polychlorinated Biphenyl (PCB) TSCA treatment standards will be placed in 55 gallon drums and disposed of at the Waste Isolation Pilot Plant (WIPP).

- The used cartridge filters $(\sim 2)$ which exceed both the TRU limit for the ERDF, and the TSCA treatment standards for PCB regulated waste (predicted PCB concentrations in the cartridge solids are $53 \mathrm{ppm}$ and $152 \mathrm{ppm}$ in the solids) currently do not have a disposal path. The cartridges will be stored until a disposal path is identified. The PCB concentrations are based on the maximum values seen in the K Basin sludges (Pearce 1998). Therefore, these values may be lower in the actual process.

The characteristics of the cartridge filters before processing (i.e., solidification) and after processing are provided in Appendix A.

\subsection{CONCLUSION}

Applying the $\mathrm{N}$ Basin solidification process to the $\mathrm{K}$ Basin residue will produce a solidified waste that complies with the ERDF waste acceptance criteria. Additionally, the waste acceptance process defined in Section 3.0 of BHI-00139 is required before the waste will be accepted at the ERDF.

Most of the cartridge filters can be solidified into a waste matrix which complies with the ERDF waste acceptance criteria. The filters which do not meet the ERDF criteria for TRU and are below the PCB treatment standards for TSCA regulated waste can be disposed of at the WIPP. The treatment process will however, produce about two cartridges which currently have no disposal path identified. The waste acceptance process defined in Section 3.0 of BHI-00139 is also required for the cartridge filters before the solidified matrix will be accepted at the ERDF. 


\section{HNF-3129, Rev. 0}

\subsection{REFERENCES}

Bernard, C., (SGN) and P. Ledermann (COGEMA), 1994, Paper: Optimization of Waste Management at the La Hague UP3 Plant, ENC '94, European Nuclear Conference, Lyon, France.

BHI, 1998, Environmental Restoration Disposal Facility Waste Acceptance Criteria, BHI-00139, Rev. 3, prepared by Bechtel Hanford, Inc. for U. S. Department of Energy Office of Environmental Restoration, Richland, Washington.

Logan, T. E., 1998, (External Letter to P. M. Pak, DOE, "Contract No. DE-AC06-93RL12367 Decision on N Basin Sediment Disposal,") Bechtel Hanford Incorporated, Richland, Washington.

Monsch, O., (SGN), C. Renard (Ondraf), J. Deckers (Belgoprocess), and P. Luycx (Belgoprocess), 1995, Paper: Treatment and Conditioning of Low-Level Radioactive Waste in Belgium: Initial Operating Results of the Cilva Facility, GLOBAL '95, International Conference on Evaluation of Emerging Nuclear Fuel Cycle Systems, Versailles, France.

Pearce, K. L., S. C Klimper and T. A. Flament, 1998, 105-K Basin Material Design Basis Feed Description for Spent Nuclear Fuel Project Facilities, Volume 2, SLUDGE, HNF-SD-SNF-TI-009, Volume 2, Rev. 2, prepared by Numatec Hanford Corporation, for Fluor Daniel Hanford, Inc., Richland, Washington.

Westra, A. G., T. A. Flament, and L. de Lamartinie, 1998, K Basin Sludge Treatment Process Description, HNF-2735, Rev. 0, prepared by Numatec Hanford Corporation, for Fluor Daniel Hanford, Inc., Richland, Washington. 
HNF-3129, Rev, 0

APPENDIX A

K BASIN RESIDUE AND FILTER CHARACTERISTICS 
HNF-3129, Rev, 0

COMPOSITION OF SOLID RESIDUES GROUTINO STREAMS

\begin{tabular}{|c|c|c|c|c|}
\hline . & 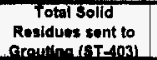 & $\begin{array}{l}\text { Supernate } \\
\text { Eliminated before } \\
\text { groutinn (ST-702) }\end{array}$ & $\begin{array}{c}\text { Grout formers (ST- } \\
703 \text { ) }\end{array}$ & $\begin{array}{l}\text { Final Grouted } \\
\text { Wastes sent to } \\
\text { ERDE (ST-704) }\end{array}$ \\
\hline $\begin{array}{l}\text { Volume } \\
\text { Density } \\
\text { Total Mas\$ } \\
\text { Liners * }\end{array}$ & $\begin{array}{r}52.1 \mathrm{m3} \\
1.097 \\
57,189.3 \mathrm{~kg}\end{array}$ & $\begin{array}{r}33.2 \mathrm{m3} \\
1.000 \\
33,161.9 \mathrm{~kg}\end{array}$ & $\begin{array}{r}17.3 \mathrm{~ms} \\
2.400 \\
41,406.6 \mathrm{~kg}\end{array}$ & $\begin{array}{r}32.0 \mathrm{m3} \\
2.046 \\
65.434 .0 \mathrm{~kg} \\
6.7\end{array}$ \\
\hline $\begin{array}{l}\text { LIOUID } \\
\text { Volume } \\
\text { Density } \\
\text { Total Mass Liquid + }\end{array}$ & $\begin{array}{r}47.4 \mathrm{~mJ} \\
1.000 \\
47,374.2 \mathrm{~kg} \\
\end{array}$ & $\begin{array}{r}33.2 \mathrm{m3} \\
1.000 \\
33,161.9 \mathrm{~kg}\end{array}$ & & \\
\hline $\begin{array}{l}\mathrm{H} 2 \mathrm{O} \\
\mathrm{HNO} 3 \\
\mathrm{H} 2 \mathrm{C} 2 \mathrm{O} 4 \\
\mathrm{HF} \\
\mathrm{NaOH} \\
\mathrm{Al}(\mathrm{NO} 3) 3 \\
\mathrm{AlF} 3 \\
\mathrm{Fe}(\mathrm{NO} 3) 3 \\
\mathrm{CaO} \\
\mathrm{NaNO} 2 \\
\mathrm{NaNO} 3 \\
\text { Miscellaneous } \\
\text { UO2(NO3)2 }\end{array}$ & $\begin{array}{r}47,328.5 \mathrm{~kg} \\
44.6 \mathrm{~kg} \\
0.3 \mathrm{~kg} \\
0.7 \mathrm{~kg}\end{array}$ & $\begin{array}{r}33,130.0 \mathrm{~kg} \\
31.2 \mathrm{~kg} \\
0.2 \mathrm{~kg} \\
0.5 \mathrm{~kg} \\
0.0 \mathrm{~kg} \\
0.1 \mathrm{~kg} \\
0.0 \mathrm{~kg} \\
\\
0.0 \mathrm{~kg} \\
0.0 \mathrm{~kg}\end{array}$ & & \\
\hline - & $\begin{array}{l}0.0 \mathrm{Ci} \\
0.0 \mathrm{Ci} \\
0.2 \mathrm{Ci} \\
0.1 \mathrm{Cl}\end{array}$ & $\begin{array}{l}0.0 \mathrm{Ci} \\
0.0 \mathrm{Ci} \\
0.1 \mathrm{Ci} \\
0.0 \mathrm{Ci}\end{array}$ & & \\
\hline$P C B$ & 00000 & $0.000 \mathrm{a}$ & & \\
\hline \begin{tabular}{|l|} 
SOLIDS + RESINS \\
Volume \\
Density \\
Total Mass solids + \\
Wr\% solids
\end{tabular} & $\begin{array}{r}4.8 \mathrm{m3} \\
2.065 \\
9,815.1 \mathrm{~kg} \\
17.16 \mathrm{wr} \%\end{array}$ & $0.00 \mathrm{wr} \%$ & $\begin{array}{r}17.3 \mathrm{~ms} \\
2.400 \\
41,406.6 \mathrm{~kg} \\
100.00 \mathrm{wr} \% \\
\end{array}$ & $\begin{array}{r}32.0 \mathrm{~ms} \\
2.046 \\
65,434.0 \mathrm{~kg} \\
100.00 \mathrm{wt \%}\end{array}$ \\
\hline $\begin{array}{l}\mathrm{Al}(\mathrm{NO} 3) 3 \\
\mathrm{Al}(\mathrm{OH}) 3 \\
\mathrm{Al} 2 \mathrm{O} 3 \\
\mathrm{Fe}(\mathrm{NO} 3) 3 \\
\mathrm{FeOOH} \\
\mathrm{C} \\
\mathrm{CaO} \\
\mathrm{Na} 2 \mathrm{C} 2 \mathrm{O} 4 \\
\mathrm{CO} 2 \\
\mathrm{H} 2 \mathrm{O} \\
\mathrm{SiO} 2 \\
\mathrm{Grout} \\
\text { Miscellaneous } \\
\text { Zircaloy } \\
\text { Grafoil } \\
\mathrm{HNO} 3 \\
\mathrm{H} 2 \mathrm{C} 2 \mathrm{O} 4 \\
\end{array}$ & $\begin{array}{r}9.7 \mathrm{~kg} \mid \\
86.2 \mathrm{~kg} \\
84.8 \mathrm{~kg} \\
336 \mathrm{~kg} \\
29.0 \mathrm{~kg} \\
\\
\\
7.426 .1 \mathrm{~kg} \\
18.1 \mathrm{~kg} \\
194.7 \mathrm{~kg} \\
52.5 \mathrm{~kg}\end{array}$ & 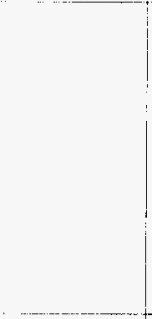 & $41.4066 \mathrm{~kg}$ & \begin{tabular}{r|}
$0.0 \mathrm{~kg}$ \\
$9.7 \mathrm{~kg}$ \\
$86.2 \mathrm{~kg}$ \\
$0.0 \mathrm{~kg}$ \\
$84.8 \mathrm{~kg}$ \\
$33.6 \mathrm{~kg}$ \\
$29.0 \mathrm{~kg}$ \\
\\
\\
$14,198.6 \mathrm{~kg}$ \\
$7,426.1 \mathrm{~kg}$ \\
$41,406.6 \mathrm{~kg}$ \\
$18.2 \mathrm{~kg}$ \\
$194.7 \mathrm{~kg}$ \\
$52.5 \mathrm{~kg}$ \\
$13.4 \mathrm{~kg}$ \\
$0.1 \mathrm{~kg}$ \\
\end{tabular} \\
\hline $\begin{array}{l}\mathrm{Na} 2 \mathrm{U}_{207} \\
\mathrm{U} \\
\mathrm{U} 3 \mathrm{O}^{7} \\
\mathrm{UH} 3 \\
\mathrm{UO} 2 \\
\mathrm{UO} 2(\mathrm{NO} 3)_{2} \\
\mathrm{UO4}-4 \mathrm{H} 2 \mathrm{O}\end{array}$ & $\begin{array}{l}0.7 \mathrm{~kg} \\
0.5 \mathrm{~kg} \\
0.1 \mathrm{~kg} \\
0.9 \mathrm{~kg} \\
0.0 \mathrm{~kg}\end{array}$ & & & $\begin{array}{l}0.7 \mathrm{~kg} \\
0.5 \mathrm{~kg} \\
0.1 \mathrm{~kg} \\
0.9 \mathrm{~kg} \\
0.0 \mathrm{~kg} \\
0.0 \mathrm{~kg}\end{array}$ \\
\hline $\begin{array}{l}\text { Fu } \\
\text { Am } \\
\text { Cs } \\
\text { Sr }\end{array}$ & $\begin{array}{r}0.6 \mathrm{Ci} \\
0.7 \mathrm{Ci} \\
47.2 \mathrm{Cl} \\
6.0 \mathrm{Ci}\end{array}$ & & & $\begin{array}{r}0.6 \mathrm{Cl} \\
0.7 \mathrm{Ci} \\
47.3 \mathrm{Ci} \\
6.0 \mathrm{Ci} \\
\end{array}$ \\
\hline$\frac{P C B}{\text { RESINS }}$ & $1,467552 \mathrm{~g}$ & & & $1,467.5529$ \\
\hline $\begin{array}{l}\text { Zeclite } \\
\text { OIEER. }\end{array}$ & $\begin{array}{r}696.5 \mathrm{~kg} \\
1,181.8 \mathrm{~kg} \\
\end{array}$ & & & $\begin{array}{r}696.5 \mathrm{~kg} \\
1,181.8 \mathrm{~kg} \\
\end{array}$ \\
\hline $\begin{array}{l}\mathrm{Pu} \\
\mathrm{Am} \\
\mathrm{Cs}\end{array}$ & $\begin{array}{r}0.506 \mathrm{Cl} \\
0.258 \mathrm{Ci} \\
74762 \mathrm{Ci}\end{array}$ & & & $\begin{array}{r}0.506 \mathrm{Ci} \\
0.258 \mathrm{Ci} \\
74.762 \mathrm{Ci} \\
\end{array}$ \\
\hline $\begin{array}{l}\text { TOTAL ACTIVITIES } \\
\text { Iotat U }\end{array}$ & $2.1 \mathrm{~kg}$ & $0.0 \mathrm{~kg}$ & & $20 \mathrm{~kg}$ \\
\hline $\begin{array}{l}\text { Tolal } P_{L} \\
\text { Total Am } \\
\text { TRU }\end{array}$ & $\begin{array}{l}11 \mathrm{Ci} \\
0.9 \mathrm{Ci} ! \\
2.0 \mathrm{Ci}\end{array}$ & $\begin{array}{l}0.0 \mathrm{Ci} \\
0.0 \mathrm{Ci} \\
0.0 \mathrm{Ci}\end{array}$ & & $\begin{array}{l}1.1 \mathrm{Cl} \\
0.9 \mathrm{Ci} \\
2.0 \mathrm{Cl}\end{array}$ \\
\hline $\begin{array}{l}\text { Total Cs } \\
\text { Total Sr } \\
\text { Beta Gamma }\end{array}$ & $\begin{array}{r}122.2 \mathrm{Ci} \\
6.1 \mathrm{Ci} \\
128.3 \mathrm{Ci}\end{array}$ & $\begin{array}{lll}0 & 1 & \mathrm{Ci} \\
0.0 & \mathrm{Ci} \\
0.2 & \mathrm{Ci}\end{array}$ & & $\begin{array}{r}122.1 \mathrm{Ci} \\
6.0 \mathrm{Ci} \\
128.1 \mathrm{Ci}\end{array}$ \\
\hline $\begin{array}{l}\text { CONCENTRATION } \\
\text { PCB in liquild } \\
\text { PCB in solids }\end{array}$ & $\begin{array}{r}0.00 \mathrm{ppb} \\
149.520 \mathrm{ppm}\end{array}$ & $0.00 \mathrm{ppb}$ & & \\
\hline $\begin{array}{l}\text { Sotids } \\
\text { U }\end{array}$ & $\begin{array}{r}149.520 \mathrm{ppm} \\
188.29 \mathrm{~g} / \mathrm{l} \\
0.000 \mathrm{~g} / \mathrm{cm} 3\end{array}$ & $0000 \mathrm{~g} / \mathrm{cm}^{3}$ & & \begin{tabular}{r|}
$22.428 \mathrm{ppm}$ \\
$2045.76 \mathrm{~g} /$ \\
$0.000 \mathrm{~g} / \mathrm{cm} 3$
\end{tabular} \\
\hline Pu total & $0.021 \mathrm{ci} / \mathrm{m}^{3}$ & $0.000 \mathrm{Cl} / \mathrm{m} 3$ & & $0.035 \mathrm{ci} / \mathrm{m}^{3}$ \\
\hline $\begin{array}{l}238 \mathrm{Fu} \\
239 \mathrm{Pu}\end{array}$ & $0.004 \mathrm{Ci} / \mathrm{m} 3$ & $0.000 \mathrm{Ci} / \mathrm{m} 3$ & & $0.007 \mathrm{Ci} / \mathrm{m} 3$ \\
\hline $\begin{array}{l}239 \mathrm{Pu} \\
240 \mathrm{Pu}\end{array}$ & $0009 \mathrm{Cl} / \mathrm{m} 3$ & $0.000 \mathrm{Ci} / \mathrm{m} 3$ & & $0.014 \mathrm{Cl} / \mathrm{m} 3$ \\
\hline $\begin{array}{l}240 \mathrm{PU} \\
\mathrm{Am}\end{array}$ & $\begin{array}{l}0.009 \mathrm{Cim} 3 \\
0.018 \mathrm{Ci} / \mathrm{m}^{3}\end{array}$ & $\begin{array}{l}0.000 \mathrm{Ci} / \mathrm{m} 3 \\
0.000 \mathrm{ci} / \mathrm{m} 3\end{array}$ & & $\begin{array}{l}0.014 \mathrm{Ci} / \mathrm{m} 3 \\
0.029 \mathrm{ci} / \mathrm{m} 3\end{array}$ \\
\hline TRU & $0.039 \mathrm{Cl} / \mathrm{m} 3$ & $0.000 \mathrm{ci} / \mathrm{m}_{3}$ & & $0.064 \mathrm{ci} / \mathrm{m} 3$ \\
\hline $\begin{array}{l}\text { TRU } \\
\text { Beta Gamma }\end{array}$ & $\begin{array}{r}36 \mathrm{nCl} / \mathrm{g} \\
2,460 \mathrm{cl} / \mathrm{m} 3\end{array}$ & $\begin{array}{r}0 \mathrm{nCl} / \mathrm{g} \\
0.005 \mathrm{ckm} 3\end{array}$ & & $\begin{array}{r}31 \mathrm{nCl} / \mathrm{s} \\
4.004 \mathrm{cl} / \mathrm{ms}\end{array}$ \\
\hline
\end{tabular}


Sludge Treatment Summars

\begin{tabular}{|c|c|c|c|c|c|c|c|}
\hline & KE1 & KE2 & KW1 & KW2 & KW3 & $\begin{array}{l}\text { Residues } \\
\text { Grouting }\end{array}$ & TOTAL \\
\hline 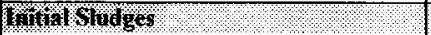 & & 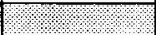 & & 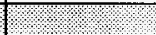 &  & 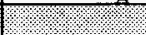 & 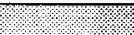 \\
\hline $\begin{array}{l}\text { Volume of as-settled sludges } \\
\%\end{array}$ & $\begin{array}{l}41.5 \mathrm{~m} 3 \\
82.0 \%\end{array}$ & $\begin{array}{l}2.4 \mathrm{~m} 3 \\
4.7 \%\end{array}$ & $\begin{array}{c}4.7 \mathrm{~m} 3 \\
9.2 \%\end{array}$ & $\begin{array}{c}0.2 \mathrm{~m} 3 \\
0.4 \%\end{array}$ & $\begin{array}{c}1.9 \mathrm{~m} 3 \\
3.7 \%\end{array}$ & & $50.58 \mathrm{m3}$ \\
\hline Total Solids & $564 \mathrm{~g} / 1$ & $1650 \mathrm{~g} / \mathrm{l}$ & $382 \mathrm{~g} / \mathrm{l}$ & $8216 \mathrm{~g} / 1$ & $1910 \mathrm{~g} / 1$ & & \\
\hline $\mathrm{U}$ & $63 \mathrm{~g} / 1$ & $1190 \mathrm{~g} / \mathrm{l}$ & $19 \mathrm{~g} / 1$ & $7375 \mathrm{~g} / 1$ & $1175 \mathrm{~g} / \mathrm{l}$ & & \\
\hline PCB in solid & $191.5 \mathrm{ppm}$ & $0.6 \mathrm{ppm}$ & $0.0 \mathrm{ppm}$ & $0.0 \mathrm{ppm}$ & $4.2 \mathrm{ppm}$ & & \\
\hline TRU & $17335 \mathrm{nCi} / \mathrm{g}$ & $192684 \mathrm{nCi} / \mathrm{g}$ & $6666 \mathrm{nCi} / \mathrm{g}$ & $265889 \mathrm{nCi} / \mathrm{g}$ & $192508 \mathrm{nCi} / \mathrm{g}$ & & \\
\hline OIER & $29.4 \mathrm{~kg} / \mathrm{m} 3$ & {$[4.4 \mathrm{~kg} / \mathrm{m} 3$} & $0.0 \mathrm{~kg} / \mathrm{m} 3$ & $0.0 \mathrm{~kg} / \mathrm{m} 3$ & $0.0 \mathrm{~kg} / \mathrm{m} 3$ & & \\
\hline Sludge treatment & ४ & (1) & (5.8. & $\sqrt{1 .} \cdot$. & & & \\
\hline Number of batches & 146.1 & 24.4 & 11.2 & 10.2 & 22.4 & & 214.4 \\
\hline Dry solids per batch & $160 \mathrm{~kg}$ & $160 \mathrm{~kg}$ & $160 \mathrm{~kg}$ & $160 \mathrm{~kg}$ & $160 \mathrm{~kg}$ & & \\
\hline Dissolution condition & $6.0 \mathrm{M}$ & $6.0 \mathrm{M}$ & $6.0 \mathrm{M}$ & $6.0 \mathrm{M}$ & $6.0 \mathrm{M}$ & & \\
\hline Conditionned wastes to ERDF & & & & & & 1.2 .0 & 1.8 .4 \\
\hline $\begin{array}{l}\text { Amount of dn residues to be grouted } \\
\%\end{array}$ & $\begin{array}{l}8.115 \mathrm{~kg} \\
82.7 \%\end{array}$ & $\begin{array}{c}297 \mathrm{~kg} \\
3.0 \%\end{array}$ & $\begin{array}{l}1,134 \mathrm{~kg} \\
11.6 \%\end{array}$ & $\begin{array}{l}150 \mathrm{~kg} \\
1.5 \%\end{array}$ & $\begin{array}{l}119 \mathrm{~kg} \\
1.2 \%\end{array}$ & $9,815 \mathrm{~kg}$ & $9,815 \mathrm{~kg}$ \\
\hline $\begin{array}{l}\text { Total amount of grouted wastes produced } \\
\text { Number of } 4.8 \mathrm{~m} 3 \text { liners drums produced } \\
\text { TRU }\end{array}$ & & & & & & $\begin{array}{c}65,434 \mathrm{~kg} \\
6.7 \\
3 \mathrm{l} \mathrm{nCi} / \mathrm{g}\end{array}$ & $\begin{array}{c}65,434 \mathrm{~kg} \\
6.7 \\
31 \mathrm{nCi} / \mathrm{g}\end{array}$ \\
\hline Whates to TWRS & & & & & 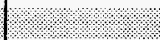 &  & 4.7 \\
\hline $\begin{array}{l}\text { Total solution sent to TWRS } \\
\%\end{array}$ & $\begin{array}{l}965.6 \mathrm{~m} 3 \\
59.6 \%\end{array}$ & $\begin{array}{c}217.4 \mathrm{~m} 3 \\
13.4 \%\end{array}$ & $\begin{array}{l}92.6 \mathrm{m3} \\
5.7 \%\end{array}$ & $\begin{array}{c}107.2 \mathrm{~m}^{3} \\
6.6 \%\end{array}$ & $\begin{array}{c}204.5 \mathrm{~m} 3 \\
12.6 \%\end{array}$ & $\begin{array}{l}33.2 \mathrm{~m} 3 \\
2.0 \%\end{array}$ & $1620 \mathrm{~m}^{3}$ \\
\hline Ratio Final Vol / Ini Vol & 5.4 & 7.5 & 6.8 & 8.9 & 7.6 & & 7.6 \\
\hline Solid concentration before water adjustem & $14 \mathrm{~g} / 1$ & $52 \mathrm{~g} / 1$ & $4.8 \mathrm{~g} / 1$ & $58 \mathrm{~g} / 1$ & $54 \mathrm{~g} / 1$ & $0.01 \mathrm{~g} / \mathrm{l}$ & $17 \mathrm{~g} / \mathrm{l}$ \\
\hline Solid concentration after water adjustemen & $14 \mathrm{~g} / 1$ & $40 \mathrm{~g} / \mathrm{l}$ & $4.8 \mathrm{~g} / \mathrm{l}$ & $40 \mathrm{~g} / \mathrm{l}$ & $40 \mathrm{~g} / \mathrm{l}$ & $0.01 \mathrm{~g} / \mathrm{l}$ & $22 \mathrm{~g} / 1$ \\
\hline PCB liq & $0.01 \mathrm{ppb}$ & $0.01 \mathrm{ppb}$ & $0.00 \mathrm{ppb}$ & $0.00 \mathrm{ppb}$ & $0.01 \mathrm{ppb}$ & $0.00 \mathrm{ppb}$ & $0.01 \mathrm{ppb}$ \\
\hline PCB sol & $0.664 \mathrm{ppm}$ & $0.005 \mathrm{ppm}$ & $0.000 \mathrm{ppm}$ & $0.000 \mathrm{ppm}$ & $0.008 \mathrm{ppm}$ & $0.001 \mathrm{ppm}$ & $0.262 \mathrm{ppm}$ \\
\hline Wys & 1.7 .4 .4 .4 & 1.6 .2 .7 & (2.. & & & & 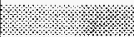 \\
\hline $\begin{array}{l}\text { Number } \\
\%\end{array}$ & $\begin{array}{c}40.4 \\
83.6 \%\end{array}$ & $\begin{array}{c}1.3 \\
2.6 \%\end{array}$ & $\begin{array}{l}5.5 \\
11.4 \%\end{array}$ & $\begin{array}{l}0.6 \\
1.2 \%\end{array}$ & $\begin{array}{l}0.6 \\
1.2 \%\end{array}$ & & 48.4 \\
\hline $\begin{array}{l}\text { PCB sol } \\
\text { TRU Activity } \\
\text { Destination }\end{array}$ & $\begin{array}{c}4.870 \mathrm{ppm} \\
29 \mathrm{nCi} / \mathrm{g} \\
\mathrm{ERDF}\end{array}$ & $\begin{array}{c}53.257 \mathrm{ppm} \\
6643 \mathrm{nCi} / \mathrm{g} \\
? \\
\end{array}$ & $\begin{array}{l}0.000 \mathrm{ppm} \\
8 \mathrm{nCi} / \mathrm{g} \\
\text { ERDF } \\
\end{array}$ & $\begin{array}{c}0.000 \mathrm{ppm} \\
5385 \mathrm{nCi} / \mathrm{g} \\
\text { WIPP } \\
\end{array}$ & $\begin{array}{c}152.172 \mathrm{ppm} \\
10386 \mathrm{nCi} / \mathrm{g} \\
?\end{array}$ & & \\
\hline
\end{tabular}


HNF-3129, Rev. 0

\section{APPENDIX B \\ ENVIRONMENTAL RESTORATION DISPOSAL FACILITY WASTE ACCEPTANCE CRITERIA}

(Excerpted From BHI-00139, Rev. 3)

B-1 


\section{HNF-3129, Rev. 0}

\section{B.1 WASTE ACCEPTANCE CRITERIA}

The Environmental Restoration Disposal Facility (ERDF) is authorized to accept waste from Hanford Site environmental restoration activities consistent with the ERDF Record of Decision (ROD) and Explanation of Significant Difference (ESD). Waste entering the ERDF shall be controlled on the basis of source, physical form, and containment levels. A uniform and consistent waste acceptance process shall be implemented to include planning, waste certification, waste shipment, and waste receipt and disposal. Waste that has not been coordinated in accordance with the waste acceptance process defined in BHI-00139 shall not be accepted at the ERDF.

The waste acceptance criteria for disposal of materials resulting from Hanford Site cleanup activities is documented in BHI-00139. This attachment provides a summary of those criteria which will apply to the $\mathrm{K}$ Basin sludge treatment secondary waste streams (residuals and filters).

\section{B.1.1 Concentration Limits}

Prior to consideration of concentration limits, the site-specific acceptance requirements must be met in accordance with the ERDF ROD and ESD. Concentration limits for chemical constituents, radionuclides, and mixed wastes are provided in the following subsections.

\section{B.1.1.1 Chemical Constituents}

The Land disposal restriction (LDR) treatment standards for dangerous/hazardous waste codes are found in Subpart D of 40 CFR 268. Table B-1 provides a partial list, by waste code, of land disposal restrictions (LDR) standards for dangerous/hazardous wastes (lists only those standards most likely to be encountered in the $\mathrm{K}$ Basin sludge residuals).

Secondary limits for various chemical constituents are identified in Table B-2. Chemicals should be evaluated against the applicable standards in Table B-1 before being evaluated against Table B-2 criteria. Limits in Table B-2 represent exposure limits determined by risk modeling in the ERDF remedial investigation/feasibility study (RI/FS) (DOE-RL 1994). Liner compatibility and worker exposure limits will be evaluated separately.

\section{B.1.1.2 Radionuclides}

Limits established for radionuclides are identified in Table B-3 (this table is not all inclusive of the radionuclides listed in BHI-00139). Where there are two or more radionuclides present in a waste, the "sum of the fractions" method (10 CFR 61.55) shall be used to determine acceptability. Each constituent in the waste mixture must be divided by the appropriate limit form Table B-3, with the sum being less than or equal to 1.0. Additional criteria for smearable surface contamination, fixed contamination, and activity levels are prescribed in the supplemental acceptance criteria (BHI 1997). Certain waste sources may require special handling to 


\section{HNF-3129, Rev. 0}

accommodate disposal at the ERDF even though the radionuclide concentrations are less than the Table B-3 limits. Handling requirements for these waste sources shall be evaluated on a case-by-case basis.

Table B-1. Land Disposal Restriction Limits for Selected Hazardous Wastes.

\begin{tabular}{|c|c|c|c|}
\hline Waste Code & Waste Description & $\begin{array}{l}\text { Regulated Hazardous } \\
\text { Constituent }\end{array}$ & $\begin{array}{l}\text { Regulatory Standard (mg/kg } \\
\text { total, unless noted otherwise) }\end{array}$ \\
\hline D001 & $\begin{array}{l}\text { Ignitable characteristic waste except for high TOC } \\
\text { subcategory }\end{array}$ & NA & Deactivate and meet UTS \\
\hline D001 & $\begin{array}{l}\text { High TOC ignitable characteristic waste }(>10 \% \\
\text { TOC) }\end{array}$ & NA & $\begin{array}{l}\text { Prohibited from disposal in } \\
\text { ERDF }\end{array}$ \\
\hline D002 & Corrosive characteristic waste & NA & Deactivate and meet UTS \\
\hline D003 & Reactive waste - water reactive subcategory & NA & Deactivate and meet UTS \\
\hline D004 & Waste that are toxic for arsenic based on TCLP & Arsenic & $5.0 \mathrm{mg} / \mathrm{TCLP}$ \\
\hline Do0s & Wastes that are toxic for barium based on TCLP & Barium & $100 \mathrm{mg} / \mathrm{L}$ TCLP \\
\hline Do06 & Wastes that are toxic for cadmium based on TCLP & Cadmium & $1.0 \mathrm{mg} / \mathrm{LCLP}$ \\
\hline D007 & Wastes that are toxic for chromium based on TCLP & Chromium (Total) & $5.0 \mathrm{mg} / \mathrm{L}$ TCLP \\
\hline D008 & Wastes that are toxic for lead based on TCLP & Lead & $5.0 \mathrm{mg} / \mathrm{LCLP}$ \\
\hline D009 & $\begin{array}{l}\text { Wastes that are toxic for mercury based on TCLP } \\
\text { and that contain less than } 260 \mathrm{mg} / \mathrm{kg} \text { total mercury }\end{array}$ & Mercury & $0.20 \mathrm{mg} / \mathrm{L} \mathrm{TCLP}$ \\
\hline D009 & $\begin{array}{l}\text { Elemental mercury contaminated with radioactive } \\
\text { materials }\end{array}$ & Mercury & Amalgamation \\
\hline D010 & Wastes that are toxic for selenium based on TCLP & Selenium & $5.7 \mathrm{mg} / \mathrm{LCLP}$ \\
\hline D011 & Wastes that are toxic for silver based on TCLP & Silver & $5.0 \mathrm{mg} / \mathrm{L} \mathrm{TCLP}$ \\
\hline $\begin{array}{l}\text { NOTE: } \\
\text { ERDF=Enviro } \\
\text { NA=not applic } \\
\text { TCLP=toxicity } \\
\text { TOC=total or: } \\
\text { UTS=universa }\end{array}$ & $\begin{array}{l}\text { Table represents a partial list of waste codes most like } \\
268 \text { should be consulted to confirm the most current st } \\
\text { mental Restoration Disposal Facility } \\
\text { ble } \\
\text { characteristics leachate procedure } \\
\text { nic carbon } \\
\text { treatment standards ( } 40 \text { CFR } 268.48 \text { ) }\end{array}$ & $\begin{array}{l}y \text { to be encountered in slud } \\
\text { indard. }\end{array}$ & ge residuals. $40 \mathrm{CFR}$ \\
\hline
\end{tabular}


HNF-3129, Rev. 0

Table B-2. Chemical Concentration Limits.

\begin{tabular}{|l|c|}
\hline \multicolumn{1}{|c|}{ Constituent Name } & Limit (mg/kg)' \\
\hline \multicolumn{2}{|c|}{ Semi-Volatile Organic Compounds } \\
\hline Benzo(a)pyrene & $2.5 \mathrm{E}+04$ \\
\hline Benzo(k)fluoranthene & $2.5 \mathrm{E}+04$ \\
\hline & \\
\hline 4,4 'DDD & $7.6 \mathrm{E}+05$ \\
\hline 4,4 'DDE & $5.4 \mathrm{E}+05$ \\
\hline PCBs & $500^{\mathrm{b}}$ \\
\hline Beta-BHC (Lindane) & $3.3 \mathrm{E}+03$ \\
\hline & \\
\hline Antimony & Metals \\
\hline Arsenic & $1.9 \mathrm{E}+04$ \\
\hline Barium & $3.0 \mathrm{E}+03$ \\
\hline Cadmium & $9.4 \mathrm{E}+05$ \\
\hline Chromium (total) & $3.9 \mathrm{E}+04$ \\
\hline Chromium VI & $5.9 \mathrm{E}+04$ \\
\hline Manganese & $5.9 \mathrm{E}+04$ \\
\hline Selenium & $4.4 \mathrm{E}+05$ \\
\hline Silver & $4.0 \mathrm{E}+05$ \\
\hline Thallium & $3.5 \mathrm{E}+05$ \\
\hline Vanadium & $5.6 \mathrm{E}+03$ \\
\hline Zinc & $3.3 \mathrm{E}+05$ \\
\hline 'Public exposure is limiting. \\
'See Section B.2.3 \\
PCB=polychlorinated biphenyl & $3.0 \mathrm{E}+05$ \\
\hline
\end{tabular}


HNF-3129, Rev. 0

Table B-3. ERDF-WAC Radionuclide Concentration Limits.

\begin{tabular}{|c|c|c|}
\hline Constituent & $\operatorname{Limit}\left(C V \mathbf{m}^{3}\right)^{\prime}$ & Notes \\
\hline Americium-241 & $5.0 \mathrm{E}-02$ & $\mathrm{~b}, \mathrm{e}$ \\
\hline Americium-243 & $5.7 \mathrm{E}-02$ & $c, e$ \\
\hline Carbon-14 & $5.3 \mathrm{E}+00$ & c \\
\hline Carbon-14 & $5.3 \mathrm{E}+01$ & $c, d$ \\
\hline Cesium-137 & $3.2 \mathrm{E}+01$ & b \\
\hline Europium-152 & 2.1E+07 & b \\
\hline Neptunium-237 & $1.5 \mathrm{E}-03$ & b,e \\
\hline Plutonium-238 & $1.5 \mathrm{E}+00$ & b,e \\
\hline Plutonium-239 & $2.9 \mathrm{E}-02$ & $\mathrm{~b}, \mathrm{e}$ \\
\hline Plutonium-240 & $2.9 \mathrm{E}-02$ & b,e \\
\hline Plutonium-241 & $6.2 \mathrm{E}+00$ & $c, e$ \\
\hline Plutonium-242 & $1.1-01$ & $\mathrm{c}$ \\
\hline Radium-228 & $2.2 \mathrm{E}-04$ & b \\
\hline Strontium -90 & $7.0 \mathrm{E}+03$ & f \\
\hline Technetium-99 & $1.3 \mathrm{E}+00$ & $\mathrm{c}$ \\
\hline Thorium-228 + Daughters & $1.2 \mathrm{E}-04$ & b \\
\hline Thorium-232 & $6.0 \mathrm{E}-03$ & c \\
\hline Uranium-233/234 & $7.4 \mathrm{E}-02$ & b \\
\hline Uranium-235 & $2.7 \mathrm{E}-03$ & b \\
\hline Uranium-238 + Daughters & $1.2 \mathrm{E}-02$ & b \\
\hline Zirconium-93 & $1.4 \mathrm{E}+02$ & c \\
\hline
\end{tabular}

${ }^{A}$ Radioactive waste Class $\mathrm{C}$ limits also apply (10 CFR 61).

${ }^{B}$ Remedial Investigation and Feasibility Study Report for the Environmental Restoration Disposal Facility (DOE-RL 1994).

C Derived from the Environmental Restoration Disposal Facility Performance Assessment (BHI 1995).

D Limit if nuclide contained in activated metal.

E ERDF limit is lower of indicated value and transuranic limit of $100 \mathrm{nCi} / \mathrm{g}$.

'Class $\mathrm{C}$ limit per $10 \mathrm{CFR} 61$.

a $100 \mathrm{nCi} / \mathrm{g}$ is the Class $\mathrm{C}$ limit for alpha-emitting transuranic nuclides with half-lives greater than 5 years.

${ }^{\mathrm{H}}$ Limit in nanocuries per gram of waste. 


\section{HNF-3129, Rev. 0}

\section{B.2 SPECIAL-CASE WASTE TYPES}

Acceptance criteria and/or restrictions associated with special-case waste types are identified in the following subsections. Centralized waste treatment may be performed at the ERDF for specific sources in accordance with the ROD Amendment to render a previously restricted waste acceptable for disposal. In such cases, ERDF users shall obtain authorization for waste treatment at the ERDF from the ERDF management and operations team prior to shipment.

\section{B.2.1 Ion Exchange Resins and Granular Activated Carbon}

Ion exchange resins and granular activated carbon must be thoroughly drained and stabilized before they are transported to prevent reaction with their surroundings and the generation of excessive heat. Containers shall be vented and/or a catalyst pack may be required if the material is capable of generating gas. Ion exchange resins and granular activated carbon may be subject to restrictions associated with organic carbonaceous compounds, as specified in Section 1.2.3.

\section{B.2.2 Debris}

Special requirements for debris are listed below.

- The initial determination of whether a waste is dangerous/hazardous debris shall be made at the source in accordance with WAC 173-303-040, 40 CFR 268.45 and other applicable waste designation requirements. After waste has been identified as dangerous/hazardous debris, it shall be so stated as part of the waste profile.

- Unless exempted by the U.S. Environmental Protection Agency (EPA), dangerous/hazardous debris shall comply with the debris treatment standards (40 CFR 268.45) or the otherwise applicable LDR treatment standard. Although sampling of treated dangerous/hazardous debris to demonstrate compliance is not required, documentation of conformance with the technology performance and operating or design standards shall be provided. Under the EPA rule, treated dangerous/hazardous debris is excluded from the definition of dangerous/hazardous waste, provided that the dangerous/hazardous debris is treated to the performance or design and operation standards by an extraction or destruction technology and the treated dangerous/hazardous debris does not exhibit a characteristic of dangerous/hazardous waste. An additional option for management of debris is a contained-in determination made by the lead regulatory agency pursuant to 40 CFR 261.3(f)(2). Excluded dangerous/hazardous debris may be disposed of in an industrial landfill (Subtitle D) and shall be accepted for disposal at the ERDF only on a case-by-case basis. 
- Waste containing more than one type of debris or one hazardous constituent shall be treated to meet the standards for each hazardous constituent and each type of debris as applicable.

\section{B.2.3 Polychlorinated Biphenyl Compounds}

Waste containing polychlorinated biphenyl (PCB) concentrations of greater than 50 parts per million (ppm) shall be managed in accordance with 40 CFR 761. Bulk liquids not exceeding $500 \mathrm{ppm}$ PCB concentrations may be disposed of at the ERDF provided that the waste is pretreated and/or stabilized to eliminate the presence of free liquids prior to final disposal. Containers of liquid PCB concentrations not exceeding $500 \mathrm{ppm}$ may be disposed of at the ERDF provided that each container is surrounded by an amount of inert sorbent material capable of absorbing all of the liquid contents of the container. Liquid waste containing PCB concentrations of greater than $500 \mathrm{ppm}$ cannot be disposed of at the ERDF.

Nonliquid PCBs in the form of contaminated soil, rags, or other debris may be disposed of at the ERDF (this includes nonliquid waste with PCB concentrations greater than $500 \mathrm{ppm}$ ).

\section{B.2.4 General Restrictions}

The following materials are prohibited from being disposed at the ERDF (the following is not all inclusive of the materials listed in BHI-00139):

- $\quad$ Transuranic waste, as defined in Appendix A (DOE Order 5820.2A II 2.a.).

- Spent nuclear fuel and high-level waste (DOE Order 5820.2A I 3.d.).

The following materials are restricted from disposal at the ERDF until the listed conditions have been met:

- Bulk disposal of waste containing free liquids, unless the free liquids are eliminated by stabilization (adding materials to chemically immobilize the free liquids in the waste) before disposal at the ERDF. Use of sorbent materials to solidify (physically immobilize) the free liquids is not permitted for bulk disposal (WAC 173-303-140[4][b] and 40 CFR 264.314[b]). If necessary, the presence of free liquids shall be determined by EPA Method 9095 ("Paint Filter Liquids Test") (EPA 1986) before shipment to the ERDF (WAC 173-303-140 [4][b] and 40 CFR 264.314[d]).

- Pyrophoric waste, unless treated, prepared, and packaged to be nonflammable prior to being disposed (DOE Order 5820.2A III 3.i.[5][f]). 


\section{HNF-3129, Rev. 0}

- Solid acid waste that exhibits the characteristic of low pH under the corrosivity tests of WAC 173-303-090(6)(a)(ii) or (iii), unless exempted pursuant to WAC 173-303-140 or the Revised Code of Washington (RCW) 70.105.050(2).

- Dangerous/hazardous waste with greater than $10 \%$ organic/carbonaceous compounds, unless exempted pursuant to WAC $173-303-140$ or RCW 70.105.050(2).

\section{B.3 PHYSICAL LIMITS}

Packaged waste shall be structurally stable (10 CFR 61.56b) for disposal at the ERDF. Packaged waste that is not structurally stable may be accepted at ERDF on a case-by-case basis and stabilized before disposal. Depending on the waste stream, stabilization may be accomplished by using soil, cement-based, or other stabilization agents with acceptable structural characteristics, size reduction, a mixture of biodegradable waste and stabilizing agents, and/or voids filled with stabilization agents. Additional physical limits for waste forms including concrete, steel plate, piping and tube steel, building debris, structural steel, containerized waste, equipment, soft waste, and rebar are defined in the supplemental waste acceptance criteria (BHI 1997).

\section{B.4 DEFINITIONS}

Carbonaceous Waste: Dangerous/hazardous waste that contains combined concentrations of greater than $10 \%$ organic/carbonaceous constituents. Organic/carbonaceous constituents are those substances that contain carbon-hydrogen, carbon-halogen, or carbon-carbon chemical bonding.

Dangerous/hazardous Debris: Debris that contains a dangerous/hazardous waste listed in Subpart D of 40 CFR 261, or that exhibits a characteristic of dangerous/hazardous waste identified in Subpart C of 40 CFR 261.

Debris: Solid material exceeding a $60-\mathrm{mm}$ particle size that is intended for disposal and is a manufactured object, plant or animal matter, or natural geologic material. However, the following materials are not considered to be debris: any material for which a specific treatment standard is provided in Subpart D of 40 CFR 268, namely lead acid batteries, cadmium batteries, and radioactive lead solids; process residuals, such a smelter slag and residues from the treatment of waste, wastewater, sludges, or air emission residues; and intact containers of dangerous/hazardous waste that are not ruptured and that retain at least $75 \%$ of their original volume. A mixture of debris and other material that has not been treated to the standards provided by 40 CFR 268.45 is subject to regulation as debris if the mixture is composed primarily of debris, by volume, based on visual inspection.

Free Liquids: Liquids that can readily separate from the solid portion of a waste under ambient temperature and pressure. 


\section{HNF-3129, Rev. 0}

Solidification: A technique that limits the solubility and mobility of dangerous/hazardous waste constituents by bonding or chemically reacting with the stabilizing material.

Structural Stability: A structurally stable waste form will generally maintain its physical dimensions and its form under the expected disposal conditions, such as weight of overburden and compaction equipment, the presence of moisture and microbial activity, and internal factors such as radiation effects and chemical changes. Structural stability can be provided by the waste form itself, processing the waste to a stable form, or placing the waste in a disposal container or structure that provides stability after disposal.

Supplemental Waste Acceptance Criteria: Acceptance criteria established for operational radiological controls and physical limits for bulk shipments at the ERDF.

Transuranic Waste: Waste that is contaminated with alpha-emitting transuranium radionuclides with half-lives greater than 20 years and concentrations greater than $100 \mathrm{nCi} / \mathrm{g}$ at the time of assay.

Treatment: Any method, technique, or process designed to change the physical or chemical character of waste to render it less hazardous; make the waste safer to transport, store, or dispose of; or reduce the waste in volume.

\section{B.5 REFERENCES}

BHI, 1995, Environmental Restoration Disposal Facility Performance Assessment, BHI-00169, Rev. 0, Bechtel Hanford, Inc., Richland, Washington.

BHI, 1997, Supplemental Waste Acceptance Criteria for Bulk Shipments to the Environmental Restoration Disposal Facility, 0000X-DC-W0001, Rev. 1, Bechtel Hanford, Inc., Richland, Washington.

BHI, 1998, Environmental Restoration Disposal Facility Waste Acceptance Criteria, BHI-00139, Rev. 3, Bechtel Hanford, Inc., Richland, Washington.

10 CFR 61, "Licensing Requirements for Land Disposal of Radioactive Waste," Code of Federal Regulations, as amended.

40 CFR 264, "Standards for Owners and Operators of Hazardous Waste Treatment, Storage, and Disposal Facilities," Code of Federal Regulations, as amended.

40 CFR 268, "Land Disposal Restrictions," Code of Federal Regulations, as amended. 


\section{HNF-3129, Rev. 0}

DOE-RL, 1994, Remedial Investigation and Feasibility Study Report for the Environmental Restoration Disposal Facility, DOE/RL-93-99, Rev. 1, U.S. Department of Energy, Richland Operations Office, Richland, Washington.

DOE Order 5820.2A, Radioactive Waste Management, as amended, U.S. Department of Energy, Washington, D.C.

WAC 173-303, "Dangerous Waste Regulations," Washington Administrative Code, as amended. 


\section{DISTRIBUTION SHEET}

\begin{tabular}{|c|c|c|c|c|c|}
\hline \multirow{2}{*}{$\begin{array}{l}\text { To } \\
\text { Distribution }\end{array}$} & \multirow{2}{*}{\multicolumn{3}{|c|}{$\begin{array}{l}\text { From } \\
\text { Numatec Hanford Corporation } \\
\text { sludge Treatment Project }\end{array}$}} & \multicolumn{2}{|l|}{ Page 1 of 1} \\
\hline & & & & \multicolumn{2}{|c|}{ Date August 26,1998} \\
\hline \multirow{2}{*}{\multicolumn{4}{|c|}{$\begin{array}{l}\text { Project Title/Work Order } \\
\text { Solidification Process for sludge Residue, HNF-3129 }\end{array}$}} & \multirow{2}{*}{\multicolumn{2}{|c|}{$\begin{array}{l}\text { EDT No. } \\
\text { ECN No. }\end{array}$}} \\
\hline & & & & & \\
\hline Name & MSIN & $\begin{array}{c}\text { Text } \\
\text { With } \\
\text { All } \\
\text { Attach } \\
\text {. }\end{array}$ & $\begin{array}{l}\text { Text } \\
\text { Only }\end{array}$ & $\begin{array}{c}\text { Attach. } \\
\text { Appendi } \\
\text { x } \\
\text { Only }\end{array}$ & $\begin{array}{l}\text { EDT } / E C N \\
\text { Only }\end{array}$ \\
\hline $\begin{array}{l}\text { Correspondence Control } \\
\text { Fluor Daniel Hanford, Inc. }\end{array}$ & A3-01 & $x$ & & & \\
\hline $\begin{array}{l}\text { M. J. Wiemers } \\
\text { DEES Hanford, Inc. }\end{array}$ & R3-11 & $\mathrm{x}$ & & & \\
\hline $\begin{array}{l}\text { D. E. Bullock } \\
\text { D. R. Prechectel }\end{array}$ & $\begin{array}{l}R 3-86 \\
\times 3-85\end{array}$ & $\begin{array}{l}\mathrm{x} \\
\mathrm{x}\end{array}$ & & & \\
\hline Numatec Hanford Corporation & & & & & \\
\hline $\begin{array}{l}\text { L. de Lamartinie } \\
\text { T. A. Flament } \\
\text { S. C. Klimper } \\
\text { W. C. Miller } \\
\text { F. W. Moore } \\
\text { K. L. Pearce } \\
\text { W. W. Rutherford } \\
\text { A. G. Westra } \\
\text { K Basins File }\end{array}$ & $\begin{array}{l}\text { H7 }-20 \\
H 7-20 \\
H 7-20 \\
H 5-25 \\
H 7-20 \\
H 7-20 \\
H 7-20 \\
R 3-86 \\
\times 3-85\end{array}$ & $\begin{array}{l}\mathrm{x} \\
\mathrm{x} \\
\mathrm{x} \\
\mathrm{x} \\
\mathrm{x} \\
\mathrm{x} \\
\mathrm{x} \\
\mathrm{x} \\
\mathrm{x}\end{array}$ & & & \\
\hline
\end{tabular}

